\title{
Yield and nitrogen recovery of lettuce under different irrigation regimes
}

\author{
F. Karam1, O. Mounzer1, F. Sarkis² and R. Lahoud1
}

${ }^{1}$ Lebanese Agricultural Research Institute, Department of Irrigation and Agro-Meteorology, Tal Amara, P.O. Box 287 Zahlé, Lebanon. ${ }^{2} E c o l e$ Supérieure d'Ingénieurs d'Agronomie Méditerranéenne, Taanayel, P.O Box 159 Zahlé, Lebanon. Corresponding author: Fadi Karam, Tal Amara, P.O. Box 287 Zahlé, Lebanon.

Phone: 9618900037 Fax: 9618900077 E-mail: fkaram@larileb.com

\begin{abstract}
Studies were conducted to determine the effect of irrigation regime on yield and nitrogen recovery of field grown lettuce in the Bekaa Valley of Lebanon, under non limiting soil $\mathrm{N}$ conditions. Within the experimental plots, irrigation differentiation was made upon crop evapotranspiration (ETC) measured on a non-weighing lysimeter of $16 \mathrm{~m}^{2}$. The treatments included a control, l-100, irrigated at $100 \%$ of ETc, and two water deficit treatments, I-80 and I-60, irrigated at $80 \%$ and $60 \%$, of ETc, respectively. Prior to planting, all plots received fertilizers broadcast at a rate of $250 \mathrm{~kg} \mathrm{ha}^{-1}$ of NPK-fertilizer (17\%). At 6-leaf and 12-leaf stages, ammonium nitrate (34.5\%) was applied with irrigation water in two applications of $125 \mathrm{~kg} \mathrm{ha}^{-1}$ each. Local groundwater containing $10 \mathrm{mg} \mathrm{l}^{-1} \mathrm{~N}^{-\mathrm{NO}_{3}}$ was used for irrigation. Yield was determined in a final destructive harvest. Crop evapotranspiration reached on the lysimeter a total of $433 \mathrm{~mm}$ for a total growing period of 70 days. Results showed that water stress caused by the deficit irrigations significantly reduced leaf number, leaf area index and dry matter accumulation $(p<0.05)$. Water deficit also reduced final fresh weight by $20 \%$ to $30 \%$ with comparison to the control. Nitrogen recovery reached $218 \mathrm{~kg} \mathrm{~N} \mathrm{ha}^{-1}$ at maturity as compared to control, while consistent reductions averaging $35 \%$ and $40 \%$ were observed on I-80 and I-60, respectively. Nitrogen use efficiency (NUE) also decreased markedly in to the less irrigated treatments. Finally, it could be concluded that nitrogen inputs from groundwater was considerable as a component of the soil nitrogen balance and increased the potential of $\mathrm{N}$ loss with leaching as a source of point pollution.
\end{abstract}

Key words: Irrigation regime, water deficit, nitrogen recovery, nitrogen use efficiency, Lactuca sativa.

\section{Introduction}

Lettuce (Lactuca sativa) for fresh consumption is an important field vegetable crop in Lebanon. It is commonly grown on the clay loam and clay soils of the Bekaa Valley under irrigated conditions. Annually, around 1500 hectares are cropped under lettuce, but knowledge of the water consumptive use and the influence of different water regimes on the yield and nitrogen uptake by lettuce are still insufficient.

Management practices that sustain lettuce production and improve soil and water quality are needed. Total $\mathrm{N}$ fertilizer recommendation for lettuce varies between 150 and $200 \mathrm{~kg}$ ha ${ }^{1}$, minus available mineral nitrogen in the root zone (Doerge et al., 1991; Sørensen et al., 1994). Inadequate N supply increases the potential of $\mathrm{NO}_{3}$ leaching and, therefore, the pollution in surface and groundwater. Environment-related studies conducted at the Agricultural Research Institute in Tal Amara indicate that nitrogen contamination of groundwater may become a greater problem in the future. Present estimates indicate that $46 \%$ of the agricultural lands in Lebanon are irrigated from groundwater and 54\% from surface water (Karam and Karaa, 2000).

Power and Schepers (1989) showed that vegetables require a greater degree of management and utilize a larger $\mathrm{N}$ input than most agronomic cropping systems. Lowrance and Smittle (1998) stated that vegetables recover less $\mathrm{N}$ than agronomic crops, and, by consequence, the potential for $\mathrm{NO}_{3}$ loss is greater with the former. Brumm and Schenk (1993) showed that a supraoptimal N supply for lettuce increased the $\mathrm{N}_{\min }$ residue at harvest in the soil, and thus the risk of nitrate leaching. Sanchez (2000) demonstrated that lettuce yield increased in response to water and nitrogen. He also found that at $\mathrm{N}$ and water required for maximum yields, $88 \%$ and $77 \%$ of the applied $\mathrm{N}$ were not recovered in the above ground portions of the plants, indicating thus the potential of large nitrate-N leaching in the soil. Linville and Smith (1971) and Halberg (1989) found that poor agronomic management accompanied with an overestimation of $\mathrm{N}$ fertilization increase $\mathrm{NO}_{3}$ potential in surface and groundwater. In contrary, many researchers reported high nitrate recovery for lettuce in response to nitrogen fertilization (Maynard et al., 1976; Dominguez Gento, 1994; Sørensen et al., 1994). In that sense, Gradner and Pew (1979) demonstrated that $80 \%$ of the nitrogen absorption by lettuce occurred during the first month of the growing cycle, indicating thus the risk of nitrate leaching late in season where nitrogen uptake is not as higher as early in season.

Jackson et al. (1994), by using EPIC model, found for two cases of field grown lettuce high rates of nitrate leaching of $52 \mathrm{~kg} \mathrm{~N} \mathrm{ha}^{-1}$ and $82 \mathrm{~kg} \mathrm{~N} \mathrm{ha}^{-1}$, as a response to $\mathrm{N}$ fertilization of $81 \mathrm{~kg} \mathrm{ha}^{-1}$ and $103 \mathrm{~kg} \mathrm{ha}^{-1}$, respectively. This high $\mathrm{N}$ leaching might be attributed to a nitrate percolation beyond the rooting zone (Recous et al., 1997).

The present study was undertaken for further understanding of the response of lettuce, in terms of yield and nitrogen recovery, 
to different regimes of drip-applied water, under non limiting soil $\mathrm{N}$ conditions. It also aims to determine the potential of nitrate- $\mathrm{N}$ leaching on a fine-textured soil, for optimum irrigation management of this crop in the Bekaa Valley of Lebanon, a typical droughtprone environment of the Mediterranean region.

\section{Materials and methods}

The experiment was conducted in 1999 at Tal Amara Research Station in the central Bekaa Valley $\left(39^{\circ} 11^{\prime} \mathrm{N}\right.$ lat., $41^{\circ} 32^{\prime} \mathrm{E}$ long., $905 \mathrm{~m}$ a.s.1). The field slope is less than $0.1 \%$. Soil characteristics show $44 \%$ clay and $1.2 \%$ organic matter. The plant available water holding capacity within the top $90 \mathrm{~cm}$ is $170 \mathrm{~mm}$ (Table 1a). The allowable soil water depletion for lettuce was set at $30 \%$ of the soil available water (Doorenbos and Kassam, 1980). Before planting, the soil was sampled in the $0-90 \mathrm{~cm}$ depth to determine the amount of initial nitrogen and other chemical components (Table 1b). Irrigation water was conveyed from Terbol Pumping Station through a concrete pipe of $20 \mathrm{~cm}$ diameter and $6 \mathrm{~km}$ length, stocked in a storage reservoir before its distribution into the irrigation network. Chemical analyses carried out on irrigation water show a concentration of $\mathrm{N}_{-} \mathrm{NO}_{3}$ of $10 \mathrm{mg} \mathrm{l}^{-1}$ (Table 1c).

Lettuce (cv Royal) was sown on 18 May 1999 with a density of 12 plants per $\mathrm{m}^{2}$ in a $2200 \mathrm{~m}^{2}$ field. Prior to planting, all plots received fertilizers broadcast at a rate of $250 \mathrm{~kg} \mathrm{ha}^{-1}$ of NPK-fertilizer (17\%). At 6-leaf and 12-leaf stages, nitrogen was applied band placed as ammonium nitrate $(34.5 \%)$ with irrigation water in two applications of $125 \mathrm{~kg} \mathrm{ha}^{-1}$ each. Nitrogen was applied at $100 \%$ level on all treatments, according to the fertilizer recommendation for lettuce given by Doerge et al. (1991), taking into account the initial soil $\mathrm{N}$ in the soil depth $0-90 \mathrm{~cm}$.

The experiment was laid out as split-plot design with three treatments representing the irrigation application levels in four replicates each. Statistical analysis was carried out through analysis of variance (ANOVA) and the treatment means were compared using Duncan's Multiple Range Test (DMRT) at 5\% of probability (Colla et al., 1999).

Experimental procedures: Crop establishment was studied by observing emergence and early crop growth. The number of emerged leaves was recorded daily as a function of the sum of temperature-day (Fig. 1). Fresh and dry weight of individual heads were taken at 7-day interval on samples of 5 plants randomly harvested from the sampling area of each plot. A leaf area meter (LI 202, Li-Cor, Inc., Lincolin, NE) measured leaf area of sampled plants. Total dry matter was determined after oven-drying the samples at $75^{\circ} \mathrm{C}$ for 48 hours. Nitrogen uptake was derived from dry weight in which total nitrogen concentration was determined by a micro-Kjeldahl method (Bremner and Mulvaney, 1982). Total dry matter and $\mathrm{N}$ concentration were used to calculate total $\mathrm{N}$ accumulation in the plant. The amount of $\mathrm{N}$ that was applied but not recovered was calculated by subtracting $\mathrm{N}$ accumulated in the aboveground portion from the total $\mathrm{N}$ applied (Sanchez, 2000).

Crop evapotranspiration was calculated from sowing till harvest on a non-weighing lysimeter of $16 \mathrm{~m}^{2}$ area $(4 \times 4 \mathrm{~m})$ and $1.2 \mathrm{~m}$ depth, situated in the middle of the experimental plots, by subtracting the volume of drainage from the irrigation amount. The measured crop evapotranspiration from the lysimeter was used to guide irrigation application. The treatments include a control, I-100, designated to receive $100 \%$ of the soil water depletion, and two water deficit treatments, I-80 and I-60, designated to receive $80 \%$ and $60 \%$, respectively, of the soil water depletion. Irrigation differentiation started after crop establishment (25 June 1999).

Initial soil moisture content was determined in the lysimeter using gravimetric samples. Irrigation of the lysimeter was based upon a deficit of $30 \%$ of the soil water depletion in the $0-90 \mathrm{~cm}$ depth. This corresponds to an amount of $50 \mathrm{~mm}$ of water evaporation

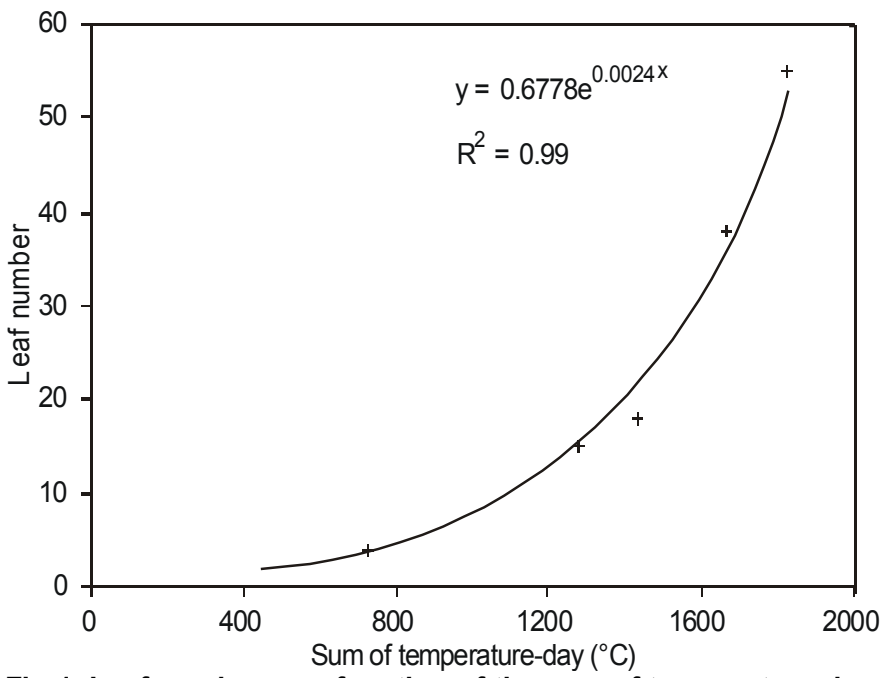

Fig.1. Leaf number as a function of the sum of temperature-day

Table 1. Soil and irrigation water analyses (average values in the $0-90 \mathrm{~cm}$ soil depth)

a) Soil physical properties

\begin{tabular}{|c|c|c|c|c|c|c|c|c|}
\hline \multicolumn{4}{|c|}{ Particle size in $\%$ of mineral parts } & \multirow[t]{2}{*}{ Soil type } & \multirow{2}{*}{$\begin{array}{l}\text { Bulk density } \\
\left(\mathrm{kg} \mathrm{dm}^{3}\right)\end{array}$} & \multicolumn{2}{|c|}{$\%$ water } & \multirow{2}{*}{$\begin{array}{l}\text { Available water } \\
(0-90 \mathrm{~cm})\end{array}$} \\
\hline$<2 \mu \mathrm{m}$ & $2-50 \mu \mathrm{m}$ & $>50 \mu \mathrm{m}$ & & & & pF 2.0 & pF 4.2 & \\
\hline 44 & 25 & 31 & & Clay & 1.41 & 29.5 & 16.0 & $170 \mathrm{~mm}$ \\
\hline \multicolumn{9}{|c|}{ b) Soil chemical properties } \\
\hline $\begin{array}{l}\text { Available } \\
\text { nitrogen } \\
\text { (kg ha-1) }\end{array}$ & $\begin{array}{l}\mathrm{P}_{2} \mathrm{O}_{5} \\
\left(\mathrm{mg} \mathrm{l}^{-1}\right)\end{array}$ & $\begin{array}{c}\mathrm{K}_{2} \mathrm{O} \\
\left.\mathrm{mg} \mathrm{l}^{-1}\right)\end{array}$ & $\begin{array}{r}\text { Exch } \\
c \\
(\end{array}$ & $\begin{array}{l}\text { geable } \\
\text { ium } \\
(-1)\end{array}$ & $\begin{array}{l}\text { Exchangeable } \\
\text { magnesium } \\
\left(\mathrm{mg} \mathrm{l}^{-1}\right)\end{array}$ & $\begin{array}{l}\text { Sodium } \\
\left(\mathrm{mg} \mathrm{l}^{-1}\right)\end{array}$ & $\overline{E l e}$ & $\begin{array}{l}\text { lectrical conductivity of } \\
1: 2 \text { soil extract } \\
\left(\mathrm{dS} \mathrm{m} \mathrm{m}^{-1}\right)\end{array}$ \\
\hline 80.0 & 30.0 & 470.0 & & 0.0 & 140.0 & 140.0 & 8.0 & 0.43 \\
\hline \multicolumn{9}{|c|}{ c) Chemical composition of the irrigation water } \\
\hline \multicolumn{3}{|c|}{ Cations (mg l-1) } & \multicolumn{3}{|c|}{ Anions (mg l-1) } & & \multirow[t]{2}{*}{$\mathrm{pH}$} & Electrical conductivity \\
\hline $\mathrm{Ca}^{2+}$ & $\mathrm{Na}^{+}$ & $\mathrm{K}^{+}$ & $\mathrm{CO}_{3}^{--}$ & $\mathrm{HCO}_{3}$ & $\mathrm{SO}_{4}$ & $\mathrm{NO}_{3}{ }^{-}$ & & $\left(\mathrm{dS} \mathrm{m}^{-1}\right)$ \\
\hline 106.0 & 9.4 & 1.5 & 0.0 & 239.0 & 17.0 & 10.0 & 7.9 & 0.53 \\
\hline
\end{tabular}


from a pan class " $A$ " situated in the middle of a weather station, $50 \mathrm{~m}$ apart from the experimental plots. Nitrate- $\mathrm{N}$ loads were calculated on the lysimeter after each irrigation. Total nitrate-N leached was summed for all leaching events below the rooting zone.

Soil moisture in the treatments was measured weekly to $90 \mathrm{~cm}$ in $30 \mathrm{~cm}$ increments, using the gravimetric sampling method. Volumetric soil water content $\left(\mathrm{q}_{\mathrm{v}}\right)$ was determined using the product of soil water measurements and the bulk density of each soil layer. Volumetric soil water was then converted into $\mathrm{mm}$ of water and accounted for each incremental soil depth $(d)$ by $\left(q_{v} \times\right.$ d)/100 (Foroud et al., 1993). Evapotranspiration under varying watering regimes was calculated using the soil water balance model (Itier et al., (1997):

$\mathrm{ET}=\mathrm{I}+\mathrm{P}-\mathrm{D}-\mathrm{R}_{\mathrm{o}} \pm \mathrm{DW}$

Where $\mathrm{I}$ is irrigation, $\mathrm{P}$ is rainfall, $\mathrm{D}$ is drainage, $\mathrm{R}_{\mathrm{o}}$ is run-off and DW is the change in soil water content in the considered interval. All terms are expressed in $\mathrm{mm}$ of water in the crop root zone ( $\mathrm{D}$ and $\mathrm{R}_{\mathrm{o}}$ were supposed equal to zero).

Water was distributed to the plots uniformly and simultaneously using a trickle irrigation system, consisting of $40 \mathrm{~m}$ long PE distribution lines, aligned W-E, $16 \mathrm{~mm}$ in diameter, $40 \mathrm{~cm}$ drippers away, each delivering $41 \mathrm{hr}^{-1}$ of irrigation capacity at $100 \mathrm{KPa}$ pressure. Trickle irrigation lines were $40 \mathrm{~cm}$ apart, equally spaced in the lettuce rows. The control unit of the system contained a fertilizer tank ( 75 liters), a disk filter, control valves and a water flow meter.

At harvest (27 July 1999), $1 \mathrm{~m}^{2}$ quadrates were sampled and all lettuces of each sample were individually weighed. In the lysimeter, all the lettuces were harvested and weighted separately. Plant material was then oven-dried and analyzed for $\mathrm{N}$ content.

Water use efficiency (WUE), was calculated as the ratio of the aboveground dry matter, at $0 \%$ humidity, per unit of water evapotranspired by the plant (Ritchie, 1983). Nitrogen Use Efficiency (NUE), or Agronomic Efficiency was calculated as the product of Apparent Recovery Nitrogen (ANR), and Physiological Efficiency (PE). The former is defined as the increase in nitrogen content in the aboveground biomass per unit of $\mathrm{N}$ fertilizer applied whereas the latter measures the increase in yield per unit of nitrogen uptake (Dalla Costa and Giovanardi, 1994; Mambelli and Grandi, 1994). NUE is then calculated as the product of ANR and PE and measures the increase in final yield per unit of applied $\mathrm{N}$-fertilizer.

Determination of nitrogen balance: Nitrogen balance was calculated on the lysimeter as the difference between nitrogen inputs and outputs (Mariotti, 1996):

$\mathrm{DS}=\mathrm{F}-\mathrm{L}-\mathrm{P} \pm \mathrm{N}_{2}$

In this equation, DS represents the difference between initial $\left(\mathrm{S}_{\mathrm{i}}\right)$ and final $\left(\mathrm{S}_{\mathrm{f}}\right)$ soil nitrogen content at the beginning and the end of the growing period; $\mathrm{F}$ is nitrogen fertilization (including initial soil $\mathrm{N}$ ); $\mathrm{L}$ is nitrogen losses by leaching; $\mathrm{P}$ is nitrogen uptake by the plant; $\mathrm{N}_{2}$ is the atmospheric nitrogen (supposed equal to zero). For the nitrogen balance calculation, DS is a gain when positive and a loss when negative.

\section{Results and discussion}

The primary effect of water deficit on lettuce growth was the reduction of leaf area as a consequence of leaf number reduction. The rate of leaf area development of stressed plants was significantly lower than plants of the control $(p<0.05)$. Leaf area index reached at 66 d.a.s (days after sowing) on the control a value of 16.0 , while reductions of 10 and $33 \%$ were obtained on I-80 and I-60, respectively (Fig. 2a). The number of mature leaves reached at harvest a total of 60 on the control, whereas in treatments I-80 and I-60 it was $8 \%$ and $14 \%$ lower $(p<0.05)$, respectively (Fig. 2b).

Water deficit produced significant differences in fresh weight of individual heads $(p<0.05)$. At 66 d.a.s, fresh weight of the well-irrigated plants averaged $757 \mathrm{~g}$, whereas treatments I-80 and I-60 showed reductions of $14 \%$ and 39\%, respectively, (Fig. $2 c)$. Moreover, significant effects $(p<0.05)$ were observed on dry matter accumulation and partitioning to leaves. Fig. $2 \mathrm{~d}$ shows that total dry matter in I-100 treatment averaged $60 \mathrm{~g} \mathrm{head}^{-1}$, while in treatments I- 80 and I-60 reductions of $30 \%$ and $38 \%$, were obtained, respectively. These reductions in dry matter accounted for the lower fresh weight in the stressed treatments.

The response of lettuce yield to water stress was also analyzed by studying the response in final fresh yield to available soil moisture. Fresh yield with the only nitrogen application used in this experiment reached on the control a total of 103 tons ha-1, whereas it decreased by $20 \%$ and $30 \%(p<0.05)$ on I-80 and I60 , respectively. Moreover, lysimeter grown lettuce showed a yield $9 \%$ higher than the control (Fig. 3). Maximum average head weight was obtained on the lysimeter $(970 \mathrm{~g})$, whereas reduction of $9 \%$ (882 g) was observed on plants of I-100 treatment. Apparently, water availability increased the weight of individual head of the control by $20 \%$ and $30 \%(p<0.05)$ in comparison with the low (I-80) and the high (I-60) water stress level, respectively (Fig. 5).

As expected, crop evapotranspiration (ETc) measured on the lysimeter exceeded slightly crop evapotranspiration of the control irrigated at $100 \%$ of soil water depletion (Fig. 4). Crop evapotranspiration reached on the lysimeter a total of $433 \mathrm{~mm}$, for a growing cycle of 70 days from sowing to harvest, whereas it was $413 \mathrm{~mm}$ on I-100 treatment. On the stressed treatments, evapotranspiration estimated by mean of the soil water balance method averaged $375 \mathrm{~mm}$ on I-80 and $337 \mathrm{~mm}$ on I-60. Daily values of crop evapotranspiration as measured on the lysimeter are shown in Fig.5. Rates of ETc were essentially low at early vegetative growth (average value of $4 \mathrm{~mm}^{\text {day }}{ }^{1}$ from 0 to 38 d.a.s), then increased gradually to about $60 \%$ (average value of $6.5 \mathrm{~mm} \mathrm{day}^{1}$ from 38 to 70 d.a.s) by the end of the growing season, where lettuce had developed the maximum number of mature leaves.

Results showed also that water deficit treatments had lower water use efficiency (WUE) than the control. WUE was $13.7 \mathrm{~kg} \mathrm{ha}^{-1}$ $\mathrm{mm}^{-1}$ on I-80 and $13.4 \mathrm{~kg} \mathrm{ha}^{-1} \mathrm{~mm}^{-1}$ on I-60, whereas that of the control was $17.6 \mathrm{~kg} \mathrm{ha}^{-1} \mathrm{~mm}^{-1}$. No consistent differences were found between the control and the lysimeter.

The response pattern of nitrogen uptake to water availability regimes shows the low $\mathrm{N}$ uptake at the beginning of the growing 

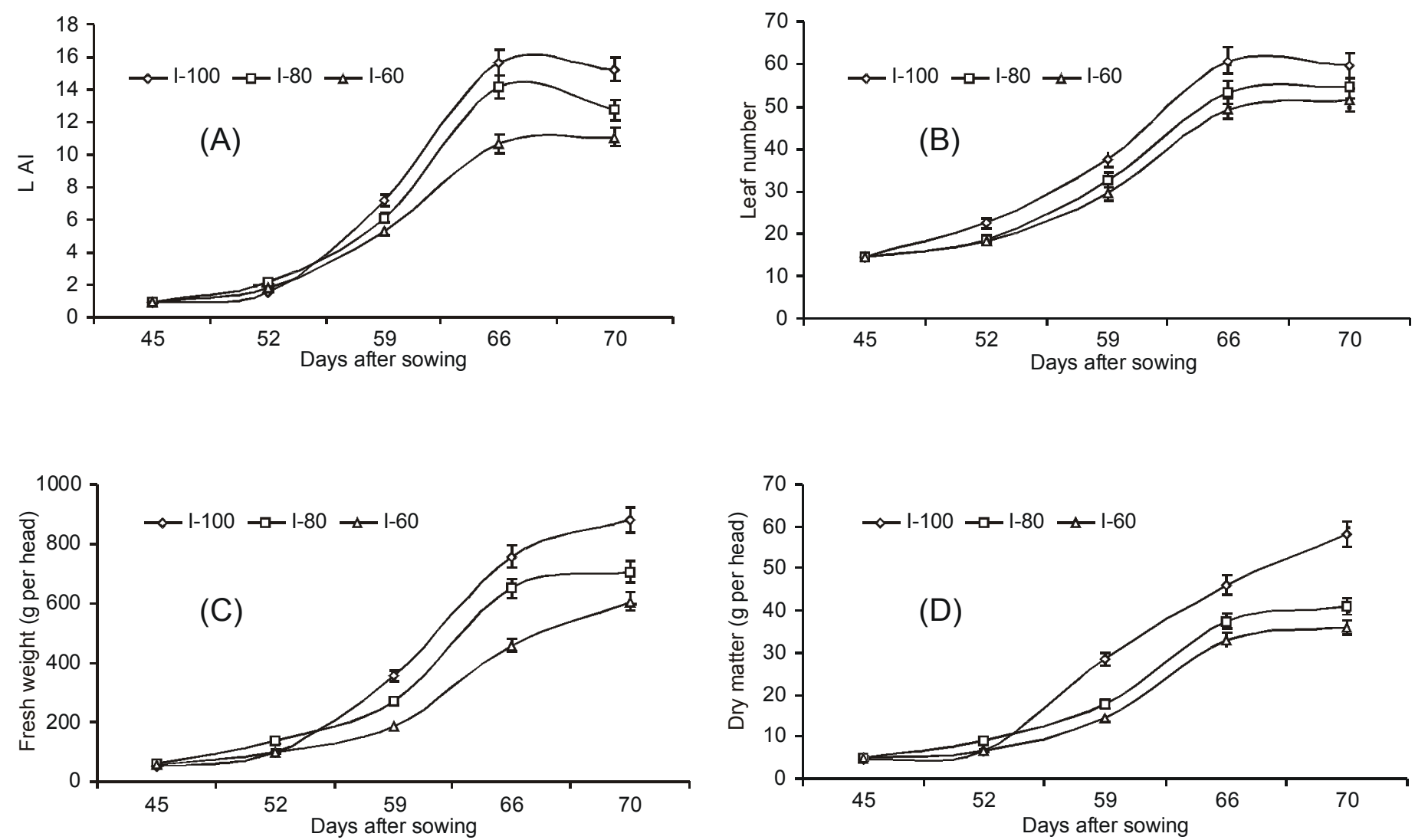

Fig. 2. Water stress effects (A) Leaf Area Index, (B) leaf number, (C) fresh weight and (D) dry matter (Data points are means of 5 plants per treatment $\pm 1 \mathrm{SE}$; bars represent confidence intervals at $5 \%$ probability)

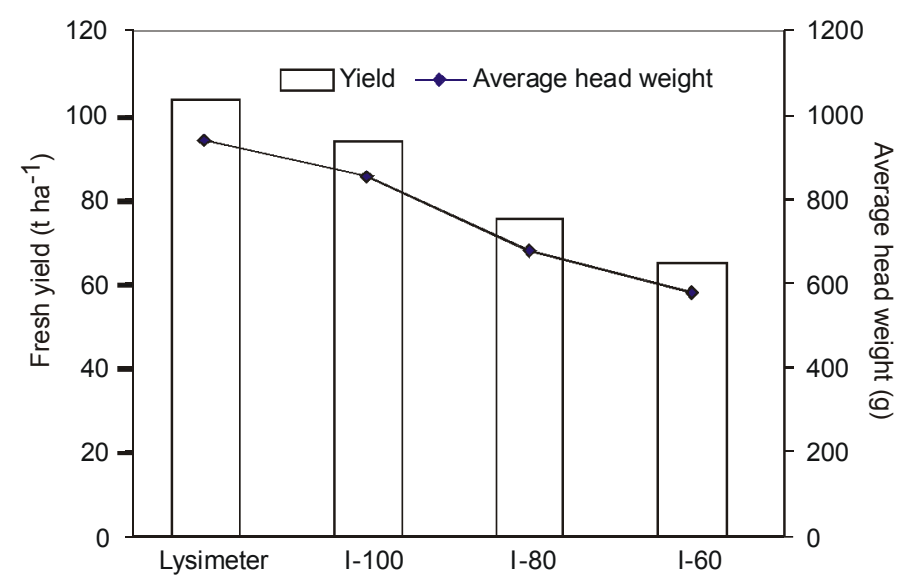

Fig. 3. Yield and average head weight of lettuce $(P<0.05)$

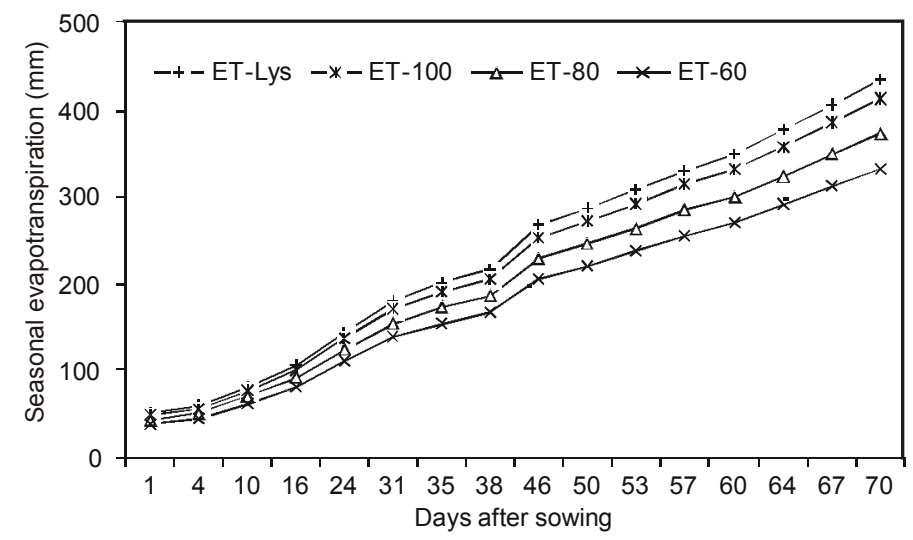

Fig. 4. Changes in evapotranspiration of the different treatments season, where an average uptake of $18 \mathrm{~kg} \mathrm{~N} \mathrm{Na}^{-1}$ was equally observed in all treatments (Fig. 6). After this period, $\mathrm{N}$ uptake increased and contrasts among treatments started to appear. At mid-cycle (59 d.a.s.), differences of $30.6 \mathrm{~kg} \mathrm{~N} \mathrm{ha}^{-1}$ and $36.6 \mathrm{~kg}$ $\mathrm{N} \mathrm{ha}^{-1}$, which correspond to uptake rates of $0.51 \mathrm{~kg} \mathrm{~N} \mathrm{ha}^{-1}$ day $^{-1}$ and $0.62 \mathrm{~kg} \mathrm{~N} \mathrm{ha}^{-1} \mathrm{day}^{-1}$, were observed between the control and I-80 and I-60, respectively. At harvest (70 d.a.s.), total nitrogen accumulated in the plant was $218 \mathrm{~kg} \mathrm{ha}^{-1}$ on I-100, $138 \mathrm{~kg} \mathrm{ha}^{-1}$ on I-80 and $133 \mathrm{~kg} \mathrm{ha}^{-1}$ on I-60, which correspond to uptake differences of 1.14 and $1.21 \mathrm{~kg} \mathrm{~N} \mathrm{ha}^{-1}$ day $^{-1}$ between the control and the water deficit treatments.

Water deficit limited the yield and depressed nitrogen use efficiency. Lettuce displayed high recovery with $\mathrm{N}$ fertilization under well-watering conditions. The obtained value in treatment I-100 was around $77 \%$ of the total applied nitrogen, while in treatments with less water availability, nitrogen recovery was near to $48 \%$ (Table 2). However, plants of the lysimeter showed a nitrogen recovery of $86 \%$. These values are higher to those reported by Sanchez (2000), but similar to those obtained by Jackson et al. (1994). Data from Table 2 show that nitrogen use efficiency (NUE) decreased in stressful conditions. In spite of similar initial soil nitrogen content of $80 \mathrm{~kg} \mathrm{ha}^{-1}$, and similar application rate of $\mathrm{N}$ fertilizer of $128.7 \mathrm{~kg} \mathrm{ha}^{-1}$, NUE efficiency changed considerably among treatments, and was reduced due to limited water availability by $25 \%$ on I- 80 and $30 \%$ on I- 60 , with comparison to the control.

Nitrogen balance calculations were made on the lysimeter according to equation (2). Data in Table 3 show that, at sowing (18 May 1999), initial soil $\mathrm{N}$ was $80 \mathrm{~kg} \mathrm{ha}^{-1}$, while final soil $\mathrm{N}$ 


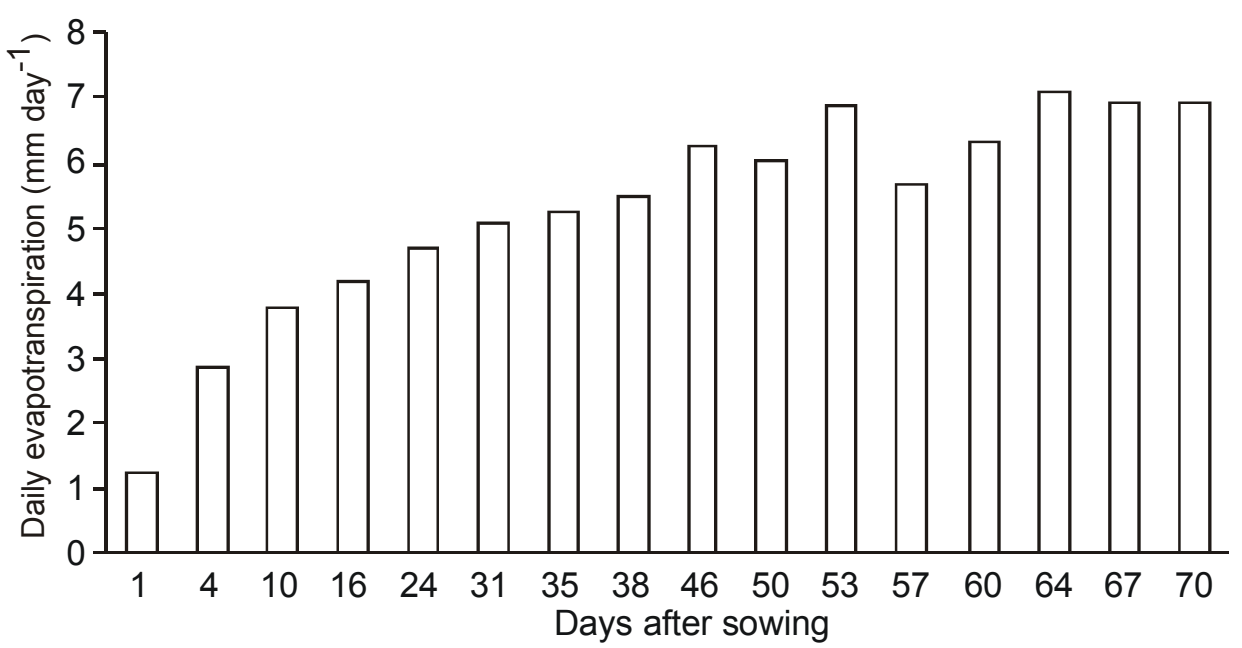

Fig. 5. Daily pattern of crop evapotranspiration as measured on the lysimeter

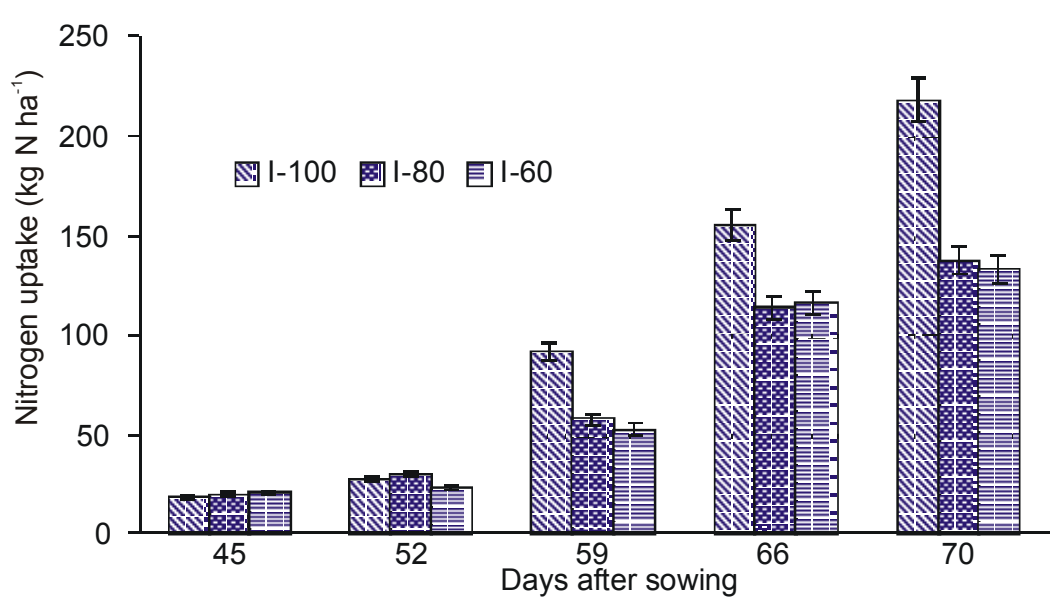

Fig. 6. Nitrogen recovery in the different treatments vs. time (Data points are means of 5 plants per treatment $\pm 1 \mathrm{SE}$; bars represent confidence intervals at $5 \%$ probability)

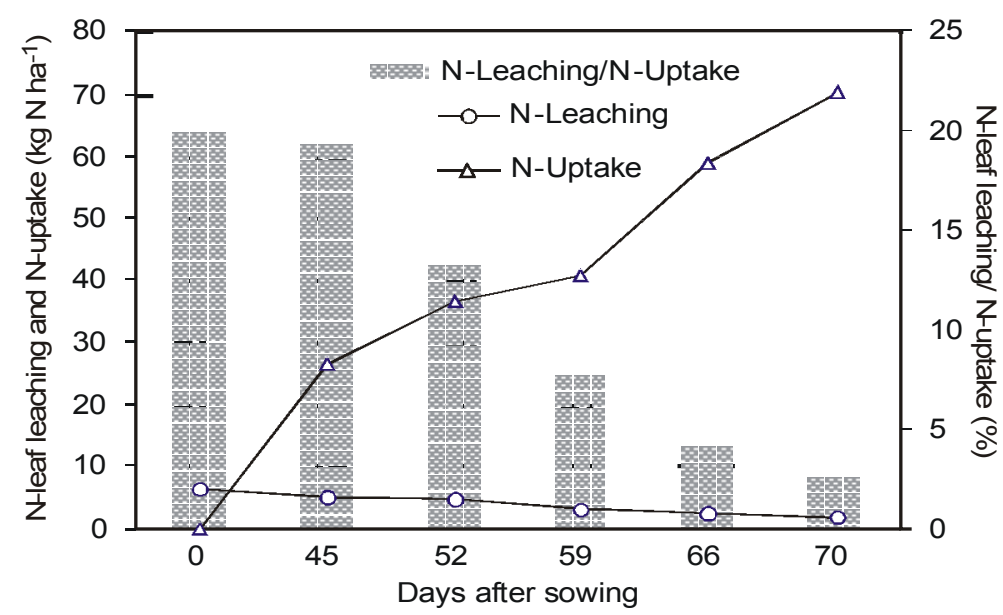

Fig. 7. N-Leaching and N-Uptake and ratio N-Leaching/N-Uptake, as measured on the lysimeter

was at harvest (27 July 1999) $13.24 \mathrm{~kg} \mathrm{ha}^{-1}$. This leads to a decrease of $66.74 \mathrm{~kg} \mathrm{ha}^{-1}$ over a total growing period of 70 days, or an average decrease of $0.953 \mathrm{~kg} \mathrm{~N} \mathrm{ha}^{-1} \mathrm{day}^{-1}$. Based on the amount of nitrogen applied $\left(128.74 \mathrm{~kg} \mathrm{ha}^{-1}\right)$, and the initial soil nitrogen $(80$ $\mathrm{kg} \mathrm{ha}^{-1}$ ), lettuce has been shown to have a high nitrogen recovery in the layer $0-90 \mathrm{~cm}$ when water and nitrogen are not limiting factors, amounting in our case a total of $232.86 \mathrm{~kg} \mathrm{ha}^{-1}$. On the other hand, nitrogen contribution from groundwater to the soil nitrogen content was considerable, reflecting thus high agricultural inputs in the use of nitrogen fertilizer in the area. In our experiment, irrigation water containing $10 \mathrm{mg} \mathrm{l}^{-1}$ of nitrate-N leads to a total amount of $61.46 \mathrm{~kg} \mathrm{Nha}^{-1}$ over the whole irrigation period, or $30 \%$ of the total $\mathrm{N}$ available in the soil (sum of initial soil $\mathrm{N}$ and mineral $\mathrm{N})$. This exceeds the nitrate-N concentration of irrigation water from Colorado River used by Sanchez (2000), or by Berndt (1993) when studying farming-associated $\mathrm{NO}_{3}$ pollution of groundwater in Georgia. Total amount of $\mathrm{N}$ leached from the lysimeter was $24.1 \mathrm{~kg} \mathrm{ha}^{-1}$ or $39 \%$ of the $\mathrm{N}$ applied with irrigation water during the whole irrigation period. At early growth stage, the ratio of $\mathrm{N}$-leaching to $\mathrm{N}$-irrigation was around $50 \%$. Then, this ratio decreases gradually throughout the season and reached by the end of the growing period a value of $26 \%$. This in reality accounted for the high nitrogen uptake by lettuce late in season, with comparison to the low uptake early in season. Our results in that sense disagree with the findings of Gardner and Pew(1979).

Moreover, nitrate- $\mathrm{N}$ leached after each irrigation was relatively high during the early growth period, then it decreased gradually when crop consumptive use became higher. This was compensated by a low $\mathrm{N}$ uptake by lettuce early in season, as indicated in Fig.7. The ratio of N-Uptake to N-Leaching decreases gradually from $20 \%$ at the beginning of the growth cycle to less than $3 \%$ at harvest time.

Finally, results of the nitrogen balance show the high inputs of nitrate-N with irrigation water. A recent survey indicate that most of the central Bekaa Valley are close or exceeded the standard of $10 \mathrm{mg} \mathrm{l}^{-1}$ of $\mathrm{N}^{-\mathrm{NO}_{3}}$ of the U.S. Bureau of Reclamation (1991). Less input of N fertilizer are typically required on the fine-textured soils of the alluvial valley for maximum lettuce yield.

Reducing irrigation by 20 and $40 \%$ of ETc had resulted in significant decrease of marketable yield $(p<0.05)$. This was accompanied by a decrease in the crop water use, as a consequence of inadequate soil moisture in the rooting zone. Results also showed that water deficit reduced average fresh weight and dry matter of individual lettuces by an average varying between 20 to $30 \%$. A significant reduction $(p<0.05)$ in the number of leaves per head was also obtained in the stressed treatments.

The maximum nitrogen uptake by lettuce plants was determined at harvest where the maximum number of leaves was reached in all irrigation treatments. The highest nitrogen uptake was observed in plants of the well-irrigated treatment and it decreased with increasing 
Table 2. Nitrogen use efficiency and its related parameters

\begin{tabular}{|c|c|c|c|c|c|c|c|c|c|c|}
\hline \multirow[t]{2}{*}{ Treatment } & & $\begin{array}{l}\mathbf{N} \text { applied } \\
\left(\mathrm{kg} \mathrm{ha}^{-1}\right)\end{array}$ & & \multirow[t]{2}{*}{$\begin{array}{l}\mathbf{N}_{\text {total }} \\
\left(\mathrm{kg} \mathrm{ha}^{-1}\right)\end{array}$} & \multirow[t]{2}{*}{$\begin{array}{l}\mathrm{N}_{\text {uptake }} \\
\left(\mathrm{kg} \mathrm{ha}^{-1}\right)\end{array}$} & \multirow[t]{2}{*}{$\begin{array}{l}\mathrm{N}_{\text {leached }} \\
\left(\mathrm{kg} \mathrm{ha}^{-1}\right)\end{array}$} & \multirow[t]{2}{*}{ ARN $^{(1)}$} & \multirow{2}{*}{$\begin{array}{c}\text { Yield } \\
(\text { kg dry } \\
\left.\text { matter ha }^{-1}\right)\end{array}$} & \multirow[t]{2}{*}{$P E^{(2)}$} & \multirow[t]{2}{*}{$A E^{(3)}$} \\
\hline & $\overline{\mathbf{N}_{\text {initial }}}$ & $\mathrm{N}_{\text {mineral }}$ & $\mathbf{N}_{\text {Irrigation }}$ & & & & & & & \\
\hline Lysimeter & 80.0 & 128.7 & 61.4 & 270.1 & 232.8 & 18.0 & $0.86 \mathrm{a}$ & $7706.2 \mathrm{a}$ & $33.09 \mathrm{a}$ & $19.93 \mathrm{a}(4)$ \\
\hline $\mid-100$ & 80.0 & 128.7 & 76.3 & 285.0 & 218.6 & - & $0.77 \mathrm{a}$ & $7275.0 \mathrm{a}$ & $33.27 \mathrm{a}$ & $19.61 \mathrm{a}$ \\
\hline $1-80$ & 80.0 & 128.7 & 71.9 & 280.6 & 138.7 & - & $0.49 \mathrm{~b}$ & $5140.0 \mathrm{~b}$ & $37.04 \mathrm{~b}$ & $14.58 \mathrm{~b}$ \\
\hline $\mid-60$ & 80.0 & 128.7 & 67.0 & 275.7 & 133.5 & - & $0.48 \mathrm{~b}$ & $4505.0 \mathrm{c}$ & $33.74 \mathrm{a}$ & $13.48 b c$ \\
\hline
\end{tabular}

(1) Apparent Recovery Nitrogen, in $\mathrm{kg} \mathrm{ha}^{-1}$ of $\mathrm{N}_{\text {uptake }}$ per kg ha-1 of $\mathrm{N}_{\text {applied }}$

(2) Physiological Efficiency, in kg of yield dry matter ha-1 per kg ha-1 of $\mathrm{N}_{\text {uptake }}$

(3) Agronomic Efficiency, or Nitrogen Use Efficiency, in kg of yield dry matter ha-1 per kg ha-1 of N applied

(4) Values followed by the same letters are not significantly different according to Duncan's Multiple Range Test $(p<0.05)$

Table 3. Nitrogen balance according to equation (2)

\begin{tabular}{|c|c|c|c|c|c|c|c|}
\hline \multirow[t]{2}{*}{ Sampling date } & \multirow[b]{2}{*}{$\begin{array}{c}\left(\mathrm{kg} \mathrm{ha}^{-1}\right) \\
(+)\end{array}$} & \multicolumn{2}{|c|}{$F\left(\mathrm{~kg} \mathrm{ha}^{-1}\right)$} & \multirow{2}{*}{$\begin{array}{c}\mathrm{L} \\
\left(\mathrm{kg} \mathrm{ha}^{-1}\right) \\
(-)\end{array}$} & \multirow{2}{*}{$\begin{array}{c}\mathrm{P} \\
\left(\mathrm{kg} \mathrm{ha}^{-1}\right) \\
(-)\end{array}$} & \multirow[b]{2}{*}{$\Leftrightarrow$} & \multirow{2}{*}{$\begin{array}{l}\Delta S \\
\left(\mathrm{~kg} \mathrm{ha}^{-1}\right) \\
( \pm)\end{array}$} \\
\hline & & $\begin{array}{c}\bar{N}-\min \\
(+)\end{array}$ & $\begin{array}{c}\text { N-Irr } \\
(+)\end{array}$ & & & & \\
\hline 18/05/1999 & $80(1)$ & 42.5 & 13.12 & 6.56 & & & 129.06 \\
\hline 02/07/1999 & 129.06 & 43.12 & 10.29 & 5.14 & 26.42 & $=$ & 150.91 \\
\hline 09/07/1999 & 150.91 & & 9.78 & 4.86 & 36.51 & $=$ & 119.32 \\
\hline 16/07/1999 & 119.32 & 43.12 & 11.75 & 3.13 & 40.7 & $=$ & 130.36 \\
\hline 23/07/1999 & 130.36 & & 9.32 & 2.48 & 58.97 & $=$ & 78.23 \\
\hline 27/07/1999 & 78.23 & & 7.20 & 1.93 & 70.26 & $=$ & $13.24^{(2)}$ \\
\hline Total & & 128.74 & 61.46 & 24.1 & 232.86 & & \\
\hline
\end{tabular}

(+) Gain; (-) Loss; ( \pm ) Nitrogen content variation in a given interval; $F=$ Fertilizer; N-min = Mineral nitrogen; N-Irr = Nitrogen with irrigation waters; $L=$ Leaching; $P=$ Nitrogen uptake by the plant; $D S=$ difference between initial $\left(S_{i}\right)$ and final $\left(S_{f}\right)$ soil nitrogen content.

(1) initial soil nitrogen $\left(S_{j}\right)$.

(2) final soil nitrogen $\left(S_{f}\right)$.

water stress level.

At harvest, residual soil nitrogen calculated on the lysimeter by means of the nitrogen balance equation was $13.2 \mathrm{~kg} \mathrm{ha}^{-1}$. This was mainly due to the high nitrogen recovery of lettuce which is an agreement with the findings of Dominguez Gento (1994). The high concentration of N-nitrate leached throughout the crop root zone reflected the high concentration of nitrate in the irrigation water, which derives from the agricultural application of $\mathrm{N}$-fertilization. A significant reduction of $\mathrm{N}$-application may lead to a reduction of inputs that will make the agro-production more sustainable. For this reason, adjustment in the dose of nitrogen fertilization is necessary for sustaining the crop production system by reducing the nitrogen inputs to avoid possible contamination of the aquifers by nitrates.

\section{Acknowledgements}

This research was supported by AUPELF-UREF, throughout its Regional Bureau in Beirut, as a part of the Master of Sciences in Sustainable Agriculture (1998-2000). We thank Mrs. Joêlle Breidy for her appreciable efforts in revising the text.

\section{References}

Berndt, M.P. 1993. National water quality assessment program. Preliminary assessment of nitrate distribution in groundwater in Georgia-Florida Coastal Plain. Study unit, 1972-1990. U.S. Geol. Surv., Earth Science info. Ctr., Denver.

Bremner, J.M. and C.S. Mulvaney, 1982. Nitrogen-total. In: A.L. Page (ed.) Methods of soil analysis. Part 2. Agronomy, 9:595-624.

Brumm, I. and M. Schenk, 1993. Influence of nitrogen supply on the occurrence of calcium deficiency in field grown lettuce. Acta Hortic., 339:125-136.

Colla, G., R. Casa, B. Lo Cascio, F. Saccardo and O. Temperini, 1999. Responses of processing tomato to water regime and fertilization in central Italy. Acta Hortic., 487:531-535, ISHS.

Dalla Costa, L. and R. Giovanardi, 1994. Nitrogen fertility and water regime influence one $\mathrm{N}$ use efficiency in sunflower and maize. Proceedings of the $3^{\text {rd }}$ Congress of the European Society for Agronomy, Abano-Padova, Italy, 98-99.

Doerge, T.A., R.L. Roth and B.R. Gardner, 1991. Nitrogen fertilizer management in Arizona. Univ. Arizona Publ., 191025.

Dominguez Gento, P. 1994. Nitrate contents in vegetables cultivated in the province of Valencia. Alimentaria, 31(249):49-51.

Doorenbos, J. and A.H. Kassam, 1986. Yield response to water. Irrigation and Drainage Bulletins 33, Food and Agriculture Organization of the United Nation, Rome.

Foroud, N., H.H. Mündel, G. Saindon and T. Entz, 1993. Effect of level and timing of moisture stress on soybean plant development and yield components. Irrigation Science, 13:149-155.

Gardner, B.R. and W.D. Pew, 1979. Comparison of various nitrogen sources of fertilizer of winter grown head lettuce. Journal of the American Society for Horticultural Science, 104:534-536.

Halberg, G.R. 1989. Nitrate in groundwater in the United States. In: R.F. Follet (ed.) Nitrogen management and groundwater protection. Elsevier, Amsterdam, 35-74.

Itier, B., N. Brisson, C. Doussan and R. Tournebize, 1997. Bilan hydrique en Agrométéorologie. In: J.M. Lagouarde and P. Cruiziat (ed.) Du Couvert Végétal à la Région. INRA, Versailles, 383-397.

Jackson, L.E., L.J. Stivers, B.T. Warden and K.K. Tanji, 1994. Crop nitrogen utilization and soil nitrate loss in a lettuce field. Fertilizer Research, 37:93-105. 
Karam, F. and K. Karaa, 2000. Recent trends in the development of a sustainable irrigated agriculture in the Bekaa valley of Lebanon. Options Méditerranéennes, 31:65-86.

Linville, K.W. and G.E. Smith, 1971. Nitrate contamination of soil cores from corn plots after repeated nitrogen fertilization. Soil Sci., 112:249-255.

Lowrance, R. and D. Smittle, 1998. Nitrogen cycling in a multiple cropvegetable production system. J. Environ. Qual., 17:158-162.

Mambelli, S. and S. Grandi, 1994. Sugarbeet nitrogen uptake in relation to fertilizer $\mathrm{N}$ rate and distribution method. In: M. Borin and $\mathrm{M}$. Sattin (ed.) Proceedings of the $3^{\text {rd }}$ Congress of the European Society for Agronomy, Abano-Padova, Italy, 174-175.

Mariotti, A. 1996. Quelques réflexions sur le cycle biogéochimique de l'azote dans les agrosystèmes. In: G. Lemaire and B. Nicolardot (ed.) Matrîse de l'azote dans les agrosystèmes, INRA, 83:9-22.

Maynard D.N., A.V. Barker and P.L. Minotti, 1976. Nitrate accumulation in vegetables. Advances in Agronomy, 28:28-117.

Power, J.F. and J.S. Schepers, 1989. Nitrate contamination of groundwater in North America. Agr. Ecosyst. Environ., 26:165187.
Recous S., B. Nicolardot and J.C. Simon, 1997. Le cycle de l'azote dans les sols et la qualité des eaux souterraines. In: R.B.C. Riou, P. Chassin, A. Neveu and F. Papy (ed.) L'eau dans l'espace rural, INRA, Paris, 193-216.

Ritchie, J.T. 1983: Efficient water use in crop production: Discussion on the generality of relations between biomass production and evapotranspiration. In: H.M. Taylor (ed.) Limitations to efficient water use in production. ASA, Madison, Wi, 29-44.

Sanchez, Ch. A. 2000. Response of lettuce to water and nitrogen on sand and the potential for leaching of nitrate-N. HortScience, 35 (1):73-77.

Sørensen, J.N., A.S. Johansen and N. Poulsen. 1994. Influence of growth and conditions on the value of crisphead lettuce: I. Marketable and nutritional quality as affected by nitrogen supply cultivar and plant age. Plant Foods for Human Nutrition, 46(1):1-11.

U.S. Bureau of Reclamation. 1991. Groundwater status report. Yuma Area-Arizona-California. 